\begin{tabular}{ll}
\hline \hline MINING AND METALLURGY INSTITUTE BOR & ISSN: 2334-8836 (Štampano izdanje) \\
UDK: 622 & ISSN: 2406-1395 (Online) \\
\hline \hline
\end{tabular}

UDK: $330.1: 673.1(510)(045)=111$

doi:10.5937/mmeb1902091D

\author{
Bojan S. Đorđević, Gabrijela Popović, Dragan Milanovic ${ }^{* * *}$
}

\title{
THE EFFECT OF MACROECONOMIC DETERMINANTS OF THE CHINESE ECONOMY ON THE COPPER PRICE MOVEMENTS ${ }^{* * * *}$
}

\begin{abstract}
The main goal of this work is to identify and analyze the impact of the Chinese economy key determinants on the global market copper price movements. Our research is based on a multilinear regression analysis of the historical data of the time period from 2003 until 2017. The presented multilinear regression model constitutes the 4 (four) statistically most significant macroeconomic variables, that is, determinants of the Chinese economy, which are used for clarifying current trends and can predict the future movements of prices on the global copper market. Statistically significant determinants are the inflation in China, the Chinese export of goods and services, Chinese import of copper, and consumption of refined copper in China. Obtained results of the research show a dominant role of the demand factor and significant influence of the Chinese economy on the movements of the global copper price. At the same time, the results imply that movements of the copper price on the global market can be an indicator of the economic activities slowing down or speeding up, in the countries which are the major traders of this metal.
\end{abstract}

Keywords: copper spot price, Chinese economy, macroeconomic factors, multiple linear regression

\section{INTRODUCTION}

Copper, one of the most important industrial metals, is the third in use (after iron and aluminum) in many industrial sectors. Its use is mostly found in the electrical and electronics industry, construction, energy, machinery and transport industry. It is unavoidable in the production of components for transmission systems of electrical energy and telecommunications, heating and cooling systems, automobile and truck systems. For example, the average car contains $1.5 \mathrm{~km}$ of copper wires, or $20-45 \mathrm{~kg}$ of copper in hybrid and electric vehicles (EV) vehicles [4]. Although copper has been exploited and used for more than 10,000 years, the new uses are being discovered every day due to increasing urbanization and demands of the global community for the use of renewable resources and environmental protection (reduction of the GHG emissions) [5,6].

Copper is now found in every built object, primarily because of its use in the electro and hydro-installations. The demand for this metal is increasingly dependent on the stability of the construction industry, the realization of infrastructure projects and the state of the real estate market. According to the latest data, the construction industry accounts for more than $35 \%$ of the total

\footnotetext{
* Faculty of Management Zaječar, Park šuma Kraljevica, Zaječar, e-mail: bojan.djordjevic@fmz.edu.rs *** Mining and Metallurgy Institute Bor

${ }^{* * * *}$ The authors are thankful to the Ministry of Education, Science and Technological Development of the Republic of Serbia for their financial support to the scientific Project TR33023 "Development of the Technology for Flotation Processinf of the Copper Ore and Precious Metals in Order to Realize Better Technological Results", of the Mining and Metallurgy Institute Bor
} 
copper consumption world wide. Namely, the copper prices dropped drastically at the end of 2008, at the height of the financial crisis and collapse of the real estate market (at least US \$ 1.26/lb on the Chicago Mercantile Exchange - CME and \$2.777/t on the London Stock Exchange - LME). This connection with construction and real estate sales showed that the price of copper during the recession during the period 2008-2009 had a high level of volatility, unlike the prices of other metals, gold and silver. Copper prices at the end of 2010 and at the beginning of 2011 were growing significantly, where in 2011 they reached their historical maximum of US $\$$ 4.62/lb and US \$10,182/t (see Figure 1).

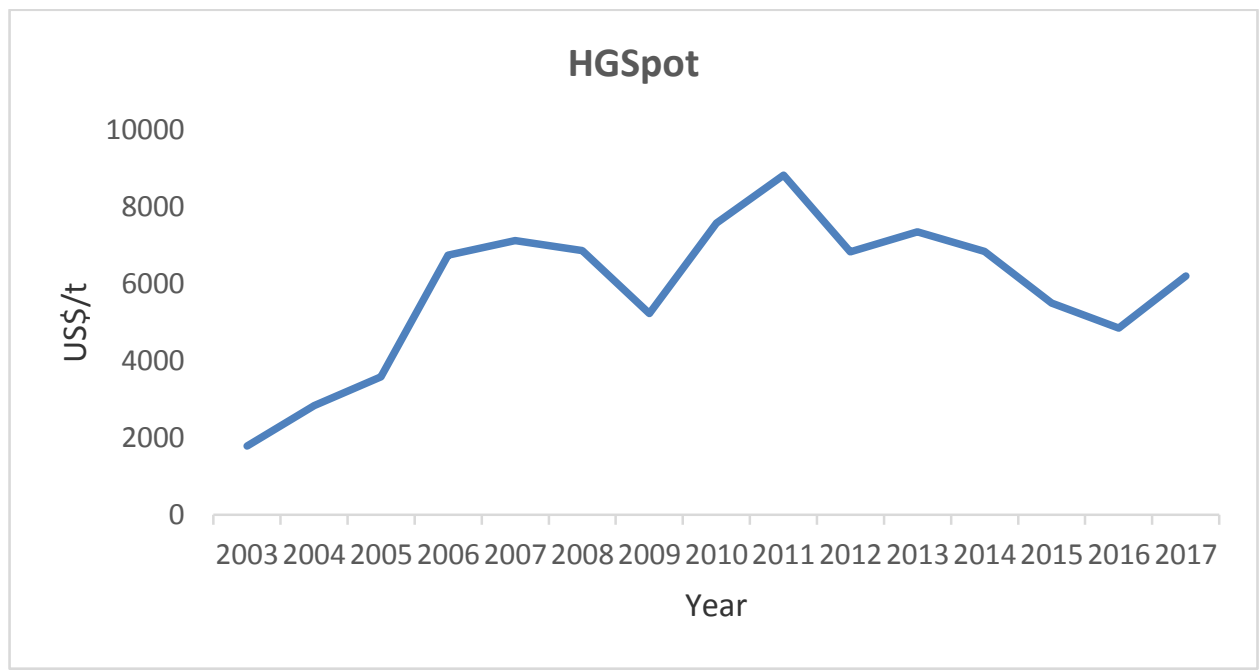

Source: Calculation of the authors on the basis of data from LME

Figure 1 Movement of the average annual spot price of copper on LME in the period 2003-2017 (US \$/t)

The issue that for decades has attracted the attention of all participants in the stock markets is how and in what way to predict the movement of prices of stock exchange goods. In theory and practice, there are different approaches for analyzing the market factors and predicting the prices of marketable materials and stock exchanges. The most common are the two approaches - fundamental and technical analysis, which today are the basic methods of many analysts and investors. Fundamental analysts (the so-called fundamentalists) try to explain and predict the movement of prices analyzing the economic, political and social factors of the environment and their impact on supply and demand $[4,5,6,7]$.
The basic principle of the fundamentalist is that any fundamental factor that leads to a reduction in supply, or increase in demand for a certain product, contributes to the rise in prices, and contrary [8,9]. According to Milenko Dželetović and Marko Milošević, the fundamental analysis starts from the macroeconomic factors, followed by the analysis of the economic environment, competitive groups and ultimately the company's performance analysis ("top to bottom" approach) [10]. As the forward prices (forwards, futures) are the future spot or prompt price, there is an increasing number of analyzes and models based on the movement of futures prices of stock markets $[11,12,13]$. 
The basic macrofundamental factors of the copper market can be divided into two basic groups: the factors on a demand side and factors on a supply side. On a demand side, it would be necessary to analyze the macroeconomic and financial performance of the economies of the largest copper consumers, as well as the consumption of copper (eg. in the US, China, India). On a supply side, the significant determinants should be sought in the economies of the largest producers and manufacturers of metal and copper ore (Chile, Peru, Australia, China), world copper reserves, metal stock exchanges, import and export of metal ore, production, trade and prices of substitute metal (such as aluminum),

Our commitment in this paper is to investigate the effect of the Chinese economy on the movement of copper prices. China today takes a significant part in the supply side, i.e. production and export of concentrates, as well as on the side of consumption and imports of refined copper in the world. The aim of this paper is to empirically identify and evaluate the key Chinese macroeconomic determinants of copper prices, and thus to provide a scientific contribution to the analysis of movement the copper prices on the world market. The subject of research is the connection between the global copper market and macroeconomic performance of the Chinese economy, the largest copper consumer in the world, in the period from 2003 to 2017. The research hypothesis, which we will try to prove, is: There is a significant statistical link and effect of the Chinese economy's determinants on movement the copper prices in the global market.

According to the above given, the work is structured in the following way: Section 2 presents the basic characteristics of the Chinese economy in the context of supply and consumption of copper; Section 3 presents the most significant results of the study on effect the macroeconomic factors on com modity prices, with a focus on metal prices (copper) and vice versa; Section 4 presents the methodology and design of our research; Section 5 presents the obtained results of a regression model with an estimate of the reliability and impartiality test of the obtained model; Section 6 gives a discussion of the research results, and Section 7 presents the conclusions.

\section{CHINESE ECONOMY AND THE WORLD MARKET OF COPPER}

Most of the world's copper supplies come from South America, especially from Peru and Chile $(38.18 \%$ of the world's total production and $31.7 \%$ of world copper reserves in 2017). On the other hand, we have the US and China, two countries that are very large copper consumers. The stability of these two largest economies has a strong impact on supply and demand for almost all goods/products. Table 1 shows the countries of the largest copper producers in 2017.

The growth of global demand for copper, as one of the main factors (in addition to the production volume and reserves) continues to play a significant role in the formation of copper prices. Based on trends in copper demand, it is assumed that it is possible to draw the conclusions about the situation in the world economy, where the reduction in demand for copper indicates a decline in the industrial activity, and therefore a weakening of the global economy, which is currently taking place with the economy of China that has been recorded in recent years stagnation of economic growth and industrial production. Namely, in this context, the movement of the gross domestic product (GDP) of the countries of the largest producers and consumers of copper in the world - China, USA, Chile, India and Australia - which in the period of 2003 2015 recorded a significant growth in its GDP, industrial production, but also consumption. The United States and China, the world's largest copper consumers, each year 
have a combined US \$ 32 trillion total of \$ 32 trillion, accounting for $39.66 \%$ of the total global GDP. It should also be noted that the industrial sectors that use copper most are growing within their national and within global GDP (construction, electrical and electronic industries, telecommunications and transport).

Table 1 World copper production and reserves in 2017 [4]*

\begin{tabular}{|c|c|c|c|c|}
\hline Country & Production (Metric Tons) & Rank & Reserves & Rank \\
\hline Australia & 920,000 & 5 & 88,000 & 2 \\
\hline Canada & 620,000 & 10 & 11,000 & 10 \\
\hline Chile & $5,330,000$ & 1 & 170,000 & 1 \\
\hline China & $\mathbf{1 , 8 6 0 , 0 0 0}$ & $\mathbf{3}$ & $\mathbf{2 7 , 0 0 0}$ & $\mathbf{6}$ \\
\hline Congo & 850,000 & 6 & 20,000 & 8 \\
\hline Indonesia & 650,000 & 9 & 26,000 & 7 \\
\hline Mexico & 750,000 & 8 & 46,000 & 4 \\
\hline Peru & $2,390,000$ & 2 & 81,000 & 3 \\
\hline USA & $1,270,000$ & 4 & 45,000 & 5 \\
\hline Zambia & 755,000 & 7 & 20,000 & 9 \\
\hline Other countries & $4,300,000$ & & 260,000 & \\
\hline Total & $\mathbf{1 9 , 7 0 0 , 0 0 0}$ & & $\mathbf{7 9 0 , 0 0 0}$ & \\
\hline
\end{tabular}

Significant growth in China is seen as an importer of copper concentrates, where the refined copper dominates on the import and consumption side with over $35 \%$ of the world's total imports, with a consumption of 3.2 million tons in 2003 to 11 million tons in 2017. Lately, due to the need for sustainable business and development, as well as growing demands for decarbonisation, China appears as a significant consumer and importer of waste copper [5]. The basic Chinese sources of waste copper imports are concentrated in highly industrialized countries and regions that include the United States, Australia, Japan and the Netherlands. Total exports from these countries exceed 2 million tons of copper. The growth of import of waste copper is shown in Figure 2. The Chinese import areas for the treatment of waste copper are located in the megalithic region of Pearl River Delta in the Guangdong district, the Yangtze River delta and Tianjin, where over $88 \%$ of copper is processed in China.

The Chinese economy should be perceived as one of the three economic powers today, affecting not only the global economic trends with its policies (eg Eurasian Economic Union with Russia and the New Road of Silk), but also daily movements in prices of commodities, interest rates, currencies. In recent years, after remarkable growth, there has been a noticeable decline in Chinese investments in regions rich in energy products and ore. First of all, this refers to the investments in the countries of Africa (Libya, Nigeria, Angola, Zambia, Congo, Ethiopia, Kenya, Cameroon, etc.), which amount to about 60 billion US\$. In African countries, the share of Chinese investment in energy products is $33 \%$ and in metals $11 \%$ of the total amount of investments. The largest volume of Chinese investments in Africa relates to the transport

\footnotetext{
* Data from USGS Mineral Commodity Summaries (2018) Data from USGS Mineral Commodity Summaries (2018), USGS, USA
} 
sectors (33\%) and energy (33\%) [7]. On the other hand, China's policy limits the foreign investment in its country, especially when it comes to energy and mining enacting the legal acts (eg. Mineral Resources Policy, Foreign Investments Guidance Catalog) [8]

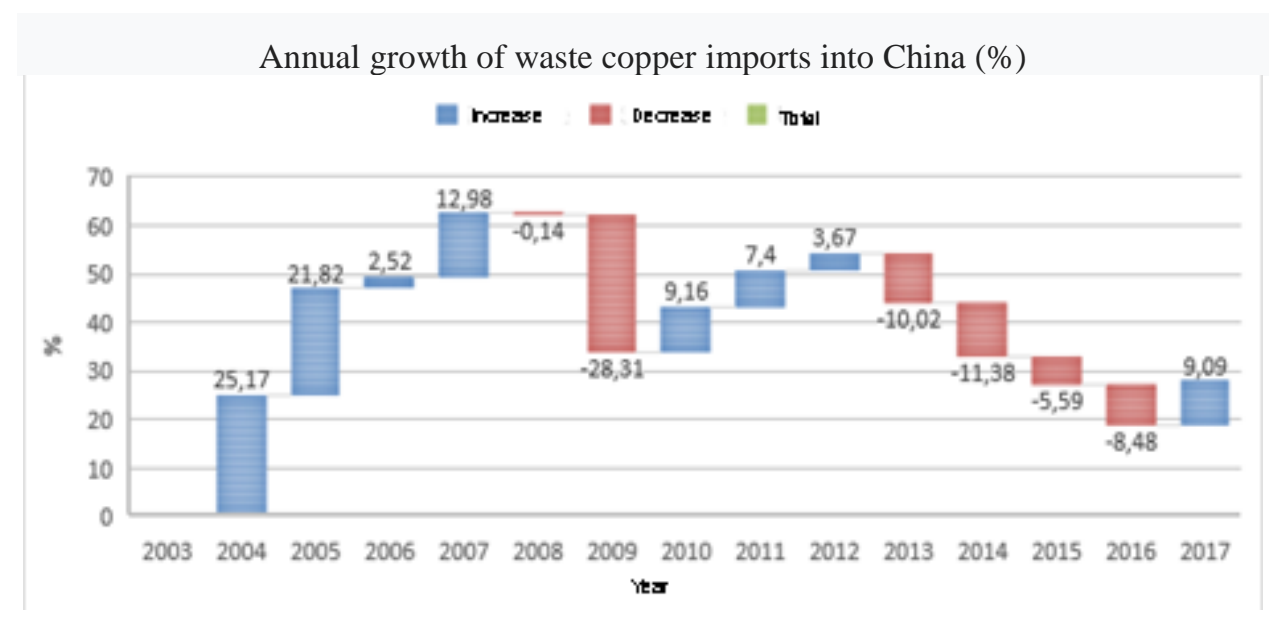

Figure 2 Chinese import of waste copper in the period from 2003 to 2017 [5]

In addition to the significant growth of traditional copper-based industries in China (construction, energy, telecommunications, electrical and electronics), an accelerated growth of the industry of transport vehicles, primarily electric vehicles (EV), has been evident in recent years. Namely, the vehicle industry (commercial and transport) in China is registering steady growth, where since 2003, when 4.5 million units of vehicles were produced, reached 29 million units in 2017 , which makes up over $43 \%$ of the world's EV production [5]. In 2011, when the rapid evolution of the EV market in China began, vehicle sales rose from 8,159 units to 798,000 in 2017 [6]. According to many forecasts, the accelerated growth of the EV market is yet to come, with projected growth above $4 \%$ per year due to acelerated urbanization and requires decarbonisation, which in many cases can be a signal of rise in the price of copper and other metals in the global market, given limited resources.

\section{REVIEW OF LITERATURE}

There is a large number of research papers dealing with analyzes of the prices of copper prices, as well as long-term forecasts of future trends in the global market. We have highlighted the most important for us in the context of our research.

Franklin Fisher, Paul Kutner, and Martin Bailey represent the econometric model of the world copper market taking the period of research 1949-1966. The basic variables of their research are grouped on the supply side of primary and secondary copper (copper production in the US and Chile, world reserves) and on the demand side for copper (world consumption, consumption in the US) [5]. Jeffrey Hill and Michael Barrou examine the linkages and the impact of interest rates on the movement of $3 \mathrm{M}$ forward prices of non-ferrous metals at LME in the period 1965-1977, where interest rates were taken from 91 UK Treasury Bill and growth rate based on the OECD Index of Industrial Production [6]. Chu Suan Tan represents the supply and demand structure and forms the 
econometric model of the copper market of Western countries, taking into account macro and microeconomic factors analysis. The most important macroeconomic determinants are related to the countries of the largest producers and consumers of copper: GDP, industrial production, primary and secondary copper production, exports and imports of metal ore and refined copper, copper and stocks [7]. Volter Labis and Alfred Mezels examine the impact of changes in prices of the agricultural products, mineral resources and energy products on the basic macroeconomic indicators of selected developed countries (GDP, industrial product, exchange rate, employment, and balance of payments) for the period 19571986. They conclude that the price fluctuations have more than expected impact on economic stability and the performance of developed economies [8]. Xun Luo, using a fundamental analysis, is a model of the futures of the crude oil market. Analyzing spot and futures prices, balance of supply and demand, interest rates, geopolitical conditions and market expectations in the period 20032006 , it can be concluded that on the basis of the application of the fundamental analysis, a model of forecasting the future prices on the energy market can be formed [9].

Antonio Gargano and Alan Timerman analyze the movement of the spot price index and the impact of macroeconomic and financial factors as a predictor. They conclude that in a long run, the industrial production and investment ratios considerably determine the price of commodity prices. Joe Victor Isler, Klaudia Rodriguez and Rafael Burdzak give understanding the fu- ture movements in metal prices, highlighting the synchronization of metal price movements with industrial cycles and industrial production [6]. Algita Miečinskiene and Indre Lapinskaite, using the multi-line regression model, represent a significant influence on the price of commodity prices on inflation (CPI) in Lithuania. Statistically significant determinants of inflation are the prices of cocoa, aluminum, copper, natural gas, coal and oil [7]. Ronald Rati and Hoakin Vespinians represent the interdependence of the M2 liquidity of the G3 and BRIC countries with the liquidity of commodity prices [8]. Eugi Kabwe and Wang Jiming analyze the world copper markets and point out the significant contribution to development the economies of China and India, increasing the world copper consumption, and thus increasing the price of this metal [9]. Tom van Gerve in his research identifies the six key fundamental indicators that determine the global copper market: warfare, technological development, economic boom, supply and demand, financial market and investment environment [10]. Jainbo Yang, Xin Li, and Kuini Liu use the ARIMA method to develop a dynamic model of predicting the copper consumption in China. Key determinants are the economic growth, consumption, urbanization, construction and transport [11].

\section{METHODOLOGY OF RESEARCH}

Our task is to form a multi-line regression model of effect the determinants of the Chinese economy on the movement of copper price, which can be represented by the following expression:

$$
Y(\text { HGSpot })=\alpha+\beta_{1} x_{1}+\beta_{2} x_{2}+\beta_{3} x_{3}+\ldots+\beta_{n} x_{n}+\varepsilon
$$

where:

$$
\begin{gathered}
\text { - } Y \text { - market copper price (annual increase } \\
\text { of copper spot prices) (HGSpot) } \\
-\alpha-\text { model constant } \\
-\beta_{1} \ldots \beta_{n}-\text { regression coefficient with } \\
\text { independent model variables } \\
\left(x_{1} \ldots x_{n}\right)
\end{gathered}
$$

- $x_{1} \ldots x_{n}$ - regressors, independent variables (annual rate of increase the Chinese economy determinants)

- $\varepsilon$ - residuals of model

10 independent variables (macroeconomic determinants of the Chinese econo- 
my) were selected in a time series of 20 years (observation), for which it is first necessary to assess the condition of a normal distribution of residuals. In the absence of a normal distribution of residuals, for all variables the logarithmic transformation will be applied. The next step is the formation of a multi-line regression model using the stepwise method, and then evaluation the standard model assumptions, i.e. reliability and impartiality of the model. The assessment of the reliability and impartiality of the model involves checking the model's standard assumptions using the following tests: multicolonarities (VIF, TOL), normal distribution of residuals (Shapiro-Wilk and JarqueBera test), homoskedasticity (BreuschPagan and White test) and autocorrelation (Durbin-Watson test). If it is determined that there is a pronounced autocorrelation of residuals, a Cohraine-Orcutt model for autocorrelation will be applied [5]. The statis- tical software SPSS 20 and XLStata Premium will be used for the analysis.

The research is based on an analysis of the annual increase in spot copper price (HGSpot) as the dependent variable $Y$, and the selected annual growth values of the determinant of the Chinese economy as independent variables $x$. The period taken for research is a time series of 20 years, i.e. from 1998 to 2017. Historical data are of the secondary character and are obtained from the official stock exchanges, global institutions and associations of producers and traders of metals (LME, CME COMEX, WTO, US Geological Survey, World Bank ...), as well as from the specialized economics portals (Trading Economics, Macrotrends etc). The annual rates of growth the spot copper prices as dependent variables are shown in Figure 3, while a description of the independent variables of the Chinese economy is given in Table 2 .

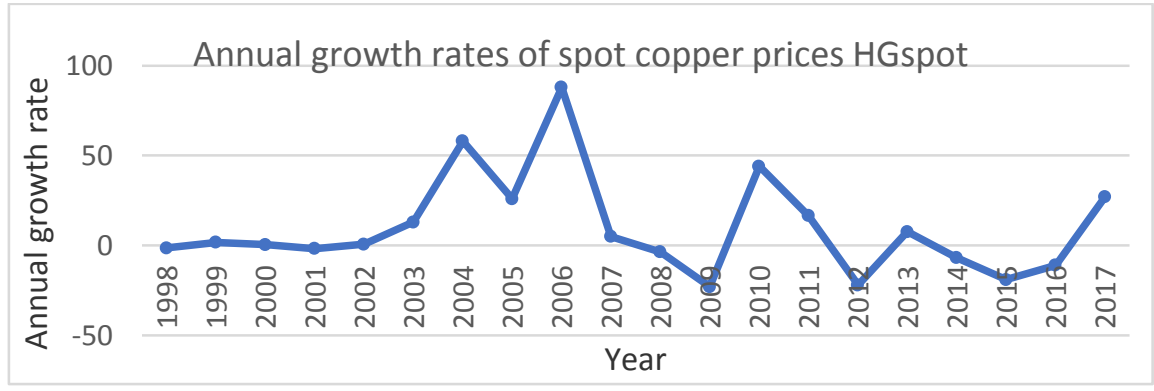

Source: Calculation of the authors on the basis of data from LME

Figure 3 Movement of the annual growth rates (\%) HGSpot (1998-2017)

Table 2 Variables of Chinese economy $\left(X_{1}-X_{10}\right)$

\begin{tabular}{|l|l|l|}
\hline & \multicolumn{1}{|c|}{ Variable } & \multicolumn{1}{c|}{ Unit } \\
\hline X1 CHNGDP & BDP of China & Annual growth $\%$ \\
\hline X2 INFCHN & Inflation rate in China (measured CPI) & Annual growth $\%$ \\
\hline X3 INDCHN & Industrial production of China & Annual growth $\%$ \\
\hline X4 EXGSCHN & Chinese exports of goods and services & Annual growth $\%$ \\
\hline X5 IMGSCHN & Chinese imports of goods and services & Annual growth $\%$ \\
\hline X6 URBCHN & Urbanization rate of China & Annual growth $\%$ \\
\hline X7 IMCOCHN & Chinese copper imports * & Annual growth $\%$ \\
\hline X8 EXCOCHN & Chinese copper exports * & Annual growth $\%$ \\
\hline X9 CRafCOCHN & Consumption of refined copper in China & Annual growth $\%$ \\
\hline X10 CNY/USD & Exchange rate Juan / US dollar & Annual growth $\%$ \\
\hline
\end{tabular}

*Include concentrate, refined and waste copper 


\section{CHECKING THE STANDARD MODELS AND RESULTS}

There are two important empirical issues that need to be considered before we begin to build models, which are the issues of structural interruptions and exogenous shocks in the observed period, i.e. time series. First, as shown in Figure 3, there is a clear structural breakdown in the price range of copper in 2003/2004, when China became the largest net importer of copper. The basic dynamics in the copper market has changed at that point, the spot price increases dramatically and becomes much more unstable. Therefore, it may be necessary to focus on the next period for model design, as in order to generate reliable properties, it is necessary that models are based on the prevailing dynamics of the structural market. Secondly, there were major changes in the spot price of copper from mid2008 to mid-2009, when the price fell sharply and then recovered rapidly. The collapse was caused by the global financial crisis, which resulted in a massive distribution of funds, as well as a decline in global trade. Then the demand for copper recovered after the stimulus package of the Chinese government, which significantly increased spending by investment in the infrastructure development and construction. Thus, we come up with three approaches to integrating variables and stationary testing. First, to include variables for the entire period 2003-2017; second, to exclude the period 2003-2004 with the included period from 2008 to 2009 , in order to take into account the extraordinary event of the financial crisis, and the third, the period of the sample could be reduced to begin only in 2010. We have opted for another approach, i.e. time series for the period 2005-2017 (13 annual observations).

First, it is necessary to evaluate the normal distribution of dependent and explanatory variables, as a precondition for applying the least squares method and fitting the initial model using the Jarque-Bera test. In the absence of a normal distribution, a logarithmic transformation will be applied in order to stabilize the variance. The next step is to form a multi-line regression model using the stepwise method of multilinear regression, and then assess the reliability and impartiality of the model parameter estimates that involve checking standard assumptions by the following tests: multicolonarities (VIF, TOL), normal distribution of residuals (ShapiroWilk and Jarque-Bera test), homoskedasticity (Breusch-Pagan and White test) and autocorrelation (Durbin-Watson test). If it is determined that there is a pronounced autocorrelation of the residual, a Cohraine-Orcutt model for the removal of autocorrelation will be applied. For statistical analysis and final model formation, the statistical software SPSS 20 and XLStata Premium will be used.

Since the initial model variables did not satisfy the condition of the normal distribution of residuals, the logarithmic transformation was applied. After that, the distribution normalization was again performed where the results obtained are shown in Table 3 .

After testing the normal values of the input variables, the stepwise method of multilinear regression was applied. The statistical parameters shown in Table 4 are obtained. We note that out of 10 input independent variables of the method, only 4 variables with a statistical significance of $0.05(95 \%)$ were singled out. Parameters of the determination coefficient indicate that the model explains $86 \%$ (adj. $\mathrm{R} 2=71.6 \%$ ) of variation the spot copper price, which is extremely high. The information criteria of AIC and SBC, as well as the F statistics, tell us that the chosen model has the good prognostic properties, i.e. that it is good for predicting $(\mathrm{F}(9.8)=5.754$, $\mathrm{p}<0.05$ ). 
Table 3 Results of normal distribution using the Jarque-Bera test

\begin{tabular}{|c|c|c|c|c|c|c|}
\hline \multicolumn{5}{|c|}{ Test of normal distribution (Jarque-Bera) } & & \\
\hline JB (Critical value $\left.-\chi^{2}\right)$ & 5.991465 & & \multicolumn{4}{|c|}{ HO- Residuals have normal distribution } \\
\hline $\mathrm{DF}$ & 2 & & \multicolumn{4}{|c|}{ Ha-Residuals have not normal distribution } \\
\hline p-value $(\alpha)$ & $>0.05$ & & & & & \\
\hline Variable & DF & JB & p -value & & & \\
\hline $\operatorname{logHGSPOT}$ & 2 & 1.885582 & 0.389539 & $\alpha>0.05$ & $J B<\gamma 2$ & HO \\
\hline $\log C H N G D P$ & 2 & 2.226438 & 0.328501 & $\alpha>0.05$ & $J B<\chi 2$ & HO \\
\hline $\operatorname{logINFCHN}$ & 2 & 1.057531 & 0.589332 & $\alpha>0.05$ & $J B<\chi^{2}$ & $\mathrm{HO}$ \\
\hline $\log$ INDCHN & 2 & 1.978232 & 0.371905 & $\alpha>0.05$ & $J B<\chi^{2}$ & $H O$ \\
\hline logEXGSCHN & 2 & 2.133446 & 0.344134 & $\alpha>0.05$ & $J B<\chi^{2}$ & $\mathrm{HO}$ \\
\hline $\operatorname{logIMGSCHN}$ & 2 & 2.037289 & 0.361084 & $\alpha>0.05$ & $J B<\chi 2$ & $\mathrm{HO}$ \\
\hline $\operatorname{logURBCHN}$ & 2 & 2.399320 & 0.301297 & $\alpha>0.05$ & $J B<\chi^{2}$ & $\mathrm{HO}$ \\
\hline $\operatorname{logIMCOCHN}$ & 2 & 1.480275 & 0.477048 & $\alpha>0.05$ & $J B<\chi^{2}$ & $\mathrm{HO}$ \\
\hline $\log \mathrm{EXCOCHN}$ & 2 & 2.605396 & 0.271798 & $\alpha>0.05$ & $J B<\chi^{2}$ & $\mathrm{HO}$ \\
\hline $\log \mathrm{CRafCOCHN}$ & 2 & 2.569074 & 0.134278 & $\alpha>0.05$ & $J B<\chi 2$ & $\mathrm{HO}$ \\
\hline $\log C N Y / U S D$ & 2 & 1.123698 & 0.354802 & $\alpha>0.05$ & $J B<\chi^{2}$ & $\mathrm{HO}$ \\
\hline
\end{tabular}

Table 4 The obtained parameters of a multilinear regression model

\begin{tabular}{|c|c|c|}
\hline \multicolumn{3}{|c|}{ Fit model results } \\
\hline Statistic & Training set & Validation set \\
\hline $\boldsymbol{D F}$ & 8.000 & -9.000 \\
\hline $\boldsymbol{R} \boldsymbol{2}$ & $\mathbf{0 . 8 6 2}$ & 65535.000 \\
\hline Adjusted $\boldsymbol{R}^{2}$ & $\mathbf{0 . 7 1 6}$ & \\
\hline $\boldsymbol{M S E}$ & 0.115 & \\
\hline $\boldsymbol{R} \boldsymbol{M} \boldsymbol{E}$ & 0.351 & \\
\hline $\boldsymbol{M A P E}$ & 361.460 & 0.000 \\
\hline $\boldsymbol{D W}$ & $\mathbf{2 . 1 1 2}$ & \\
\hline $\boldsymbol{C} \boldsymbol{p}$ & 10.000 & \\
\hline $\boldsymbol{A I C}$ & $\mathbf{- 3 1 . 9 6 0}$ & \\
\hline $\boldsymbol{S B C}$ & $\mathbf{- 2 3 . 0 4 5}$ & \\
\hline $\boldsymbol{P C}$ & 0.461 & \\
\hline
\end{tabular}

\begin{tabular}{|c|c|c|c|c|c|}
\hline \multicolumn{7}{|c|}{ ANOVA } \\
\hline Source & DF & Sum of squares & Mean squares & F & Pr $>$ F \\
\hline Model & 9 & 6.496 & 0.722 & $\mathbf{5 . 7 5 4}$ & $\mathbf{0 , 0 1 1}$ \\
\hline Error & 8 & 1.004 & 0.125 & & \\
\hline Corrected Total & 17 & 7.500 & & F $(\mathbf{9 . 8})=\mathbf{5 . 7 5 4}$. $\mathbf{p}<\mathbf{0 . 0 5}$ \\
\hline
\end{tabular}

\begin{tabular}{|c|c|c|c|c|}
\hline \multicolumn{5}{|c|}{ Parameters of model $(\alpha=0,05)$} \\
\hline Source & Value & Standard error & $\mathbf{t}$ & Pr $>|\mathbf{t}|$ \\
\hline Intercept & -0.129 & 0.136 & -0.954 & 0.368 \\
\hline logINFCHN & $\mathbf{- 0 . 7 9 8}$ & $\mathbf{0 . 3 2 1}$ & $\mathbf{- 2 . 4 8 5}$ & $\mathbf{0 . 0 3 8}$ \\
\hline logEXGSCHN & $\mathbf{1 . 1 6 5}$ & $\mathbf{0 . 4 2 0}$ & $\mathbf{- 2 . 7 7 6}$ & $\mathbf{0 . 0 2 4}$ \\
\hline $\operatorname{logIMCOCHN~}$ & $\mathbf{- 0 . 9 0 6}$ & $\mathbf{0 . 2 1 5}$ & $\mathbf{- 4 . 4 1 4}$ & $\mathbf{0 . 0 0 3}$ \\
\hline $\log$ RafCOCHN & $\mathbf{0 . 8 8 7}$ & $\mathbf{0 . 2 8 0}$ & $\mathbf{- 3 . 1 7 3}$ & $\mathbf{0 . 0 1 3}$ \\
\hline
\end{tabular}


The assessment of the reliability and impartiality of the obtained model depends on the fulfillment the model's standard assumptions [5]. The first standard assumption is to examine the absence of multicolorarity. In this test, we use two indicators: Variance Inflation Factor (VIF) and Tolerance Factor (TOL). The VIF indicator gives us an estimate of how much the variance of regression coefficient will increase due to a linear dependence with the other independent variables.
There are divided opinions which are the limits for VIF, or TOL, when testing the model. As a rule, the problem of multicolorarity does not exist when the values of VIF are $<5$ and $10(\mathrm{R} 2<0.8(0.9))$, while the values of the indicator TOL $<0.2(0.1)$. The variables whose VIF values exceed 10 should not be in the model, although it is emphasized that the values of VIF 2.5 and TOL 0.5 indicate the problem of multicolinearity [6]. The values of VIF and TOL are given in Table 5 below.

Table 5 Test results of multicolinearity

\begin{tabular}{|c|c|c|c|c|}
\hline & logINFCHN) & logEXGSCHN) & logIMCOCHN) & logCRafCOCHN) \\
\hline TOL & 0.690 & 0.194 & 0.334 & 0,599 \\
\hline VIF & 1.450 & 5.153 & 2.998 & 1,669 \\
\hline \multicolumn{3}{|c|}{ TOL average } & \multicolumn{2}{c|}{0.8975} \\
\hline \multicolumn{3}{|c|}{ VIF average } & \multicolumn{2}{c|}{017} \\
\hline
\end{tabular}

The other standard model assumption is the normal residue distribution, which was tested by Shapiro Wilk and Jarque-Bera test ( $\mathrm{HO}=$ residuals have a normal distribution). The third standard assumption of the model relates to checking the homoscedasticity/heteroscedasticity of random errors. It is necessary that the random errors show the same degree of scattering around their mean value. In case the variances of random errors differ significantly from one another, this is heteroskedasticity. Residual testing was checked using the Breusch-Pagan and White test. In the case of time series, autocorrelation of the residual is a common occurrence, which is the fourth standard assumption. Durbin-Watson test (DW) was used to detect autocorrelation. The values of DW $<2$ and DW 2, in consultation with tables $d_{1}$ and $d_{u}$, may indicate the presence of a pronounced autocorrelation of residuals. In this case, the Cohraine-Orcutt model for autocorrelation (DW transformed) is necessary. The results of all model tests are shown in Table 6.

Finally, a model of the effect of determinants of the Chinese economy on the movement of copper prices has been obtained, which has the following form:

$$
\begin{aligned}
Y(\text { HGSpot })=- & 0,798(\text { INFCHN }) \\
& +1,165(\text { EXGSCHN }) \\
& -0,906(\text { IMCOCHN }) \\
& +0,887(\text { CRAfCOCHN })
\end{aligned}
$$

On the basis of the obtained estimates of the regression coefficients, a detailed analysis the effect of the observed determinants of movement the copper prices on the global market was carried out. 
Table 6 Results of tests of normality, homoscedasticity and autocorrelation

\begin{tabular}{|c|c|c|c|}
\hline \multicolumn{4}{|c|}{ Test of normality } \\
\hline \multicolumn{2}{|l|}{ Shapiro-Wilk test } & \multicolumn{2}{|l|}{ Jarque-Bera test } \\
\hline $\mathrm{W}$ & 0.925 & JB (Observed value) & 1.396 \\
\hline P-value (2-tailed) & 0.231 & JB (Critical value) & 5.991 \\
\hline Alpha & 0.05 & DF & 2 \\
\hline \multirow{3}{*}{\multicolumn{2}{|c|}{$\begin{array}{l}W=0.925 ; \text { Sig. }=0.231>0.05=H_{0} \\
\text { Residuals have normal distribution }\end{array}$}} & P-value (2-tailed) & 0.498 \\
\hline & & Alpha & 0.05 \\
\hline & & \multicolumn{2}{|c|}{$\begin{array}{l}J B=1.396 ; \text { Sig. }=0.498>0.05=H_{0} \\
\text { Residuals have normal distribution }\end{array}$} \\
\hline \multicolumn{4}{|c|}{ Test of homoscedasticity } \\
\hline \multicolumn{2}{|c|}{ Breusch-Pagan test } & \multicolumn{2}{|c|}{ White test } \\
\hline LM (Observed value) & 0.085 & LM (Observed value) & 2.436 \\
\hline LM (Critical value) & 3.841 & LM (Critical value) & 5.991 \\
\hline DF & 1 & DF & 2 \\
\hline P-value (2-tailed) & 0.771 & P-value (2-tailed) & 0.296 \\
\hline Alpha & 0.05 & Alpha & 0.05 \\
\hline \multicolumn{2}{|c|}{$\begin{array}{c}L M=0.085 ; \text { Sig. }=0.771>0.05=H_{0} \\
\text { There is no pronounced heteroscedasticity }\end{array}$} & \multicolumn{2}{|c|}{$\begin{array}{c}L M=2.436 ; \text { Sig. }=0.296>0.05=H_{0} \\
\text { There is no pronounced heteroscedasticity }\end{array}$} \\
\hline \multicolumn{4}{|c|}{ Test of autocorrelation } \\
\hline \multicolumn{2}{|c|}{ Durbin-Watson test } & \multicolumn{2}{|c|}{ Cohraine-Orcutt model } \\
\hline \multicolumn{2}{|c|}{$\mathrm{DW}($ Original $)=2.112$} & & \\
\hline $\begin{array}{r}\text { Autocorrelation is } w \\
\text { the basis of the ta }\end{array}$ & $\begin{array}{l}\text { nits on } \\
l d l\end{array}$ & & \\
\hline
\end{tabular}

\section{DISCUSSION}

Based on the obtained $\mathrm{F}$ test results $(\mathrm{F}(9.8)=5.754, \mathrm{p}<0.05)$, we estimate that the model is adequate for analyzing the relationship between the observed variables (see Table 4). The value of the custom determination coefficient leads us to conclude that $71.6 \%$ of the variation in the spot copper price is explained by the variations of observed independent variables, the regressors (Adjusted R Square $=0.716$ ). The quality of the proposed model obtained by the stepwise regression is confirmed by the lowest values of information criteria (AIC = - 31.960; SBC = - 23.045). Regressors of the model that at a statistically significant level $(\mathrm{p}=0.05(95 \%)$ determine the move- ment of copper prices are: inflation in China (INFCHN), Chinese exports of goods and services (EXGSCHN), Chinese imports of copper (IMCOCHN) and consumption of refined copper in China (CRafCOCHN). It should be noted that at the statistical level of significance $\mathrm{p}=0.1(90 \%)$ there were several significant variables (GDP in China, imports of goods and services and Chinese copper exports), but they will not be taken into discussion.

Based on theoretical grounding and our expectations, the model has shown very interesting results. Namely, our expectations were higher in terms of strength the correlation of dependent (HGSpot) and in 
dependent variables (the variables of the Chinese economy). Also, from the equation of the regression model and coefficients we see the inverse functions, i.e. the inverse regression coefficients for the variables INFCHN and IMCOCHN, which has somewhat its theoretical and practical foundation.

The fluctuations in the price of goods, primarily energy products and agricultural products (foods), significantly contribute to the growth of consumer prices and the rise in inflation. High inflation is in the focus of all central banks, both in developed and developing economies, where sharper monetary policy measures occur during the period of growth. In this regard, the question is how much and how the state can influence the stabilization of consumer prices with its monetary policy, and thus to inflation in order to preserve social security and population standards. The characteristic of today's China, in addition to the industrialization, has accelerated the urbanization and migration of the rural population to large cities. With that, a large number of Chinese residents, due to the improvement of their living standards, are changing their lifestyle habits. According to data from the Chinese customs authorities, in 2017 food was imported in the amount of 58 billion. US \$, which is $25 \%$ more than the previous year, which indicates that the population of China is changing its eating habits. On the other hand, China is the world's largest buyer and consumer of oil, estimated at $10 \%$ of global energy consumption. The fluctuations in oil prices WTI and Brent do not affect demand, as China buys all available quantities. Currently, China does not import oil and gas from the United States due to a trade war and is facing other sources of supply, which can lead to volatility in prices and inflation, as the United States was China's significant supplier of these energy products. Analyzing the commodity correlation coefficients of crude oil and wheat, as the most important agricultural product (range 0.300.65 ), and the possibility of rising prices for these commodities, it is evident that prices and inflation are followed in China. As the copper is correlated with these goods at the intermediate level of bond strength, the impact of inflation in China measured CPI at the price of copper can be partially explained. The rest is in the domain of macroeconomic and monetary measures and unforeseen events on the market. Currently, the latest recorded inflation in China is $1.92 \%$ in 2018 (growth of $0.06 \%$ compared to 2017).

The determinant of Chinese copper imports (IMCOCHN) explains $19.3 \%$ of the variability of spot price movement of copper. We see that this is an inverse function, so that the decline in copper imports in China by $1 \%$ per annum affects the annual growth of copper prices by $0.90 \%$, and vice versa. Although China is the largest importer and consumer of refined copper in the world, this can be explained by the fact that it is at the same time the world's largest importer of ore and copper concentrates (43\% of world imports), and is increasingly reliant on the processing of secondary copper and recycling. Also, the Chinese economy receives more and more copper from its own sources and from the mines and plants they own, which makes them competitive in the world market, strengthens their bargaining power and can effect the prices through lowering demand in foreign markets.

Based on the data in Table 7, we see that the determinant of Chinese refined copper consumption (CRafCOCHN) explains $35.1 \%$ of the annual growth rate of copper spot prices (HGSpot), where the growth of refined copper consumption in China has a $1 \%$ impact on the annual increase in spot copper prices by $0.88 \%$. Due to the slowing down of the Chinese economy, in recent years there has been a decline in annual consumption of refined copper to around $3 \%$. At the same time, China has been reducing imports of refined copper in recent years due to accumulated supplies. The issue of copper stocks in China distorts the picture of consumption, according to analysts of Bloomberg and several other important financial portals. Namely, there are allegations that about $70 \%$ of refined copper 
imported into China is used to obtain credit, not for production. Chinese banks have approved the loans based on copper, as it has a certain market price and is traded on markets such as the London Metal Exchange (LME) and the Shanghai Futures Exchange (SHFE). According to the Goldman Sachs estimates, the total value of such credit arrangements reaches as much as $\$ 160$ billion. US $\$$, or about $31 \%$ of all short-term foreign currency loans in China. The last significant determinant - export of goods and services (EXGSCHN) stands on the theoretical and practical bases, with the low prediction coefficients in our model, so we will not explain it in more detail.

Table 7 Values of the coefficients of correlation and determination the model variables

\begin{tabular}{|l|l|l|l|l|l|}
\hline Pearson R & $\operatorname{logINFCHN}$ & $\operatorname{logEXGSCHN}$ & $\operatorname{logIMCOCHN}$ & $\log$ CRafCOCHN & $\operatorname{logHGSpot}$ \\
\hline $\operatorname{logINFCHN}$ & 1 & 0.370 & -0.117 & 0.068 & -0.117 \\
\hline $\operatorname{logEXGSCHN}$ & 0.370 & 1 & 0.100 & -0.143 & 0.194 \\
\hline $\operatorname{logIMCOCHN}$ & -0.117 & 0.100 & 1 & -0.388 & $\mathbf{- 0 . 4 4 0}$ \\
\hline $\log$ CRafCOCHN & 0.068 & -0.143 & -0.388 & 1 & $\mathbf{0 . 5 9 3}$ \\
\hline $\operatorname{logHGSpot}$ & -0.117 & 0.194 & $\mathbf{- 0 . 4 4 0}$ & $\mathbf{0 . 5 9 3}$ & 1 \\
\hline
\end{tabular}

\begin{tabular}{|l|l|l|l|l|l|}
\hline $\mathbf{R}^{\mathbf{2}}$ & $\operatorname{logINFCHN}$ & $\operatorname{logEXGSCHN}$ & $\operatorname{logIMCOCHN}$ & $\operatorname{logCRafCOCHN}$ & $\operatorname{logHGSpot}$ \\
\hline $\operatorname{logINFCHN}$ & 1 & 0.136 & 0.013 & 0.0046 & 0.0136 \\
\hline $\operatorname{logEXGSCHN}$ & 0.136 & 1 & 0.010 & 0.020 & 0.037 \\
\hline $\operatorname{logIMCOCHN}$ & 0.013 & 0.010 & 1 & 0.150 & $\mathbf{0 . 1 9 3}$ \\
\hline $\log$ CRafCOCHN & 0.0046 & 0.020 & 0.150 & 1 & $\mathbf{0 . 3 5 1}$ \\
\hline $\operatorname{logHGSpot}$ & 0.0136 & 0.037 & $\mathbf{0 . 1 9 3}$ & $\mathbf{0 . 3 5 1}$ & 1 \\
\hline
\end{tabular}

\section{CONCLUSION}

Correlations of copper prices with the world variables and Chinese economy are of particular importance. In recent years, the increasing influence of unclear (undetermined) factors on the price of copper, such as the investor mood, speculations and use of copper in solving the geopolitical and geoeconomic issues, is evident. These factors can further lead to the significant fluctuations in the copper price, even if basically there is no reason for such volatility. This situation on the market can be illustrated by the data from the period from 2012 to 2017 , when there was an intensive increase in production and consumption of refined copper in the world, while the copper prices recorded an intense stagnation. In 2017, owing to the slowdown in the economic growth of the world's largest economies (China and the US), the production and consumption of refined copper declined, while the average price of spot and copper fuels increased by $30 \%$. Certainly, these data tell us about the high price volatility and the extremely high level of speculative jobs on the market, which can be explained by various motives of producers and investors, from making profits to solving the geopolitical and geoeconomic issues among the strongest economies in the world (USA, EU, Russia, China).

Our research confirms effect of the Chinese economy on the movement of copper 
prices, which is evident and should not be ignored. The preliminary analysis revealed several significant features of annual series of data on the movement of copper prices: 1 . Copper copper prices had a structural break in 2003-2004, which coincides with China's entry as the largest net importer of copper to the global market, where the price series showed much higher volatility and higher average price than before; 2 . The global financial crisis in 2008 had a major impact on copper prices, as well as on other considerations. Bearing in mind the identified structural breakdown, it was decided that the period of the series should be limited to the period from 2005 to 2017 . What is somewhat surprising for the authors are the statistical insignificance and the weakness of the connections of some of the selected determi-nants to the movement of the price of copper (eg rates of GDP growth and urbanization of China). Expectations were met with the variable import of copper and the consump-tion of refined copper in China. The fact that the Chinese inflation rate is statistically significant points to the next research of economic factors, which should include other financial factors of the Chinese economy (exchange rate, interest rates, Shanghai Stock Exchange indices), as well as the impact of significant price movements - oil, steel and aluminum as the main copper substitute). Also, the analysis of trading of ETF funds on metals can be of great importance, which may explain us somewhat the influence of speculation on the price of copper.

In the end, we can conclude that we have confirmed our research hypothesis: the determinants of the Chinese economy have a statistically significant impact on the movement of prices in the global copper market. However, in order to better understand the movement of prices in the copper market, a comprehensive funda-mental analysis is needed, which, in addition to macroeconomic factors, would include microeconomic as well as factors of a political and social environment that could have an impact on the price of copper. Previously, this is confirmed by the sudden events of July 2018 on US-China relations and beginning of a trade war that continues.

\section{REFERENCES}

[1] Alison Paul (2012) "When Can You Safely Ignore Multicollinearity?", http://statisticalhorizons.com/multicollin earity (pristupljeno: 25.12.2018)

[2] Antaike Copper Research Team (2017) "Analysis of the effects of policy on the ban of 7th category copper scrap import",http://www.antaike.com/content .php?id=84742

[3] Bettman Jenni L., Sault Stephen J., Schultz Emma L. (2009) "Fundamental and Technical Analysis, Substitutes or complements", Accounting \& Finance, Vol. 49, issue 1, pp. $21-36$.

[4] Chinese Investment Tacker, AEI, (2018), http://www.aei.org/china-globalinvestment-tracker/

[5] „Copper Faces Double Supply Disruption Threat in 2018: Andy Home“,http://www.mining.com/web/co pper-faces-double-supply-disruptionthreat-2018-andy-home/

[6] de Koning Arjan, Kleijn Rene, Huppes Gjalt, Sprecher Benjamin, van Engelen Guus, Tukker Arnold (2018) "Metal supply constraints for a low-carbon economy?" Resources, Conservation and Recycling, Vol. 129, pp. 202-208.

[7] Dugalić Veroljub (2001) Price of Shared - Fundamental and Technical Analysis, Stubovi kulture, Belgrade (in Serbian)

[8] Dželetović Milenko, Milošević Marko (2017) „Fundamentalna i tehnička analiza u funkciji efikasnog upravljanja portfoliom HoV“, Poslovna ekonomija, Godina XI, br.1, str. 47 - 68 .

[9] Đorđević Bojan S. (2015) Berzansko poslovanje, Fakultet za menadžment Zaječar, Zaječar 
[10] Fisher F.M., Cootner P.H., Baily M.N., (1972) "An Econo-metric Model of the World Copper Industry“, Bell Journal of Economics, vol. 3, issue 2, pp. 568-609.

[11] Fox J., (2016) Applied Regression Analysis and Generalized Linear Models, $3^{\text {rd }}$ Edition, SAGE Publishing, Los Angeles

[12] Gargano A., Timmermann A., (2014) "Forecasting commodity price indexes using macroeconomic and financial predictors", International Journal of Forecasting, Vol. 30, no. 3, pp. 825-843.

[13] Geman H., (2005) Commodities and Commodity Derivatives: Pricing and Modeling Agricultural, Metals and Energy, Wiley Finance

[14] Gilbert C.L., (2010) "Specu-lative influences on commodity futures prices 2006-2008“, UN Conference of Trade and Development, Discussion Paper No. 197.https://unctad.org/en/ Docs/osgdp20101_en.pdf

[15] Heal G., Barrow M., (1980) "The Relationship between Interest Rates and Metal Price Movements“, The Review of Economic Studies, Vol. 47, no. 1, Econometrics Issue, pp.161-181

[16] Hertzke P., Müller N., Schenk S., (2017) "China's electric-vehicle market plugs in", McKinsey Quaterly, Dostupno na: https://www.mckinsey.com/featuredinsights/china/chinas-electric-vehiclemarket-plugs-in

[17] Irle R., (2018) "Global Plug-in Sales for the 1st Half of 2018 “,

[18] http://www.ev-volumes.com/country/ total-world-plug-in-vehicle-volumes/

[19] Issler J.V., Rodrigues C., Burjack R., (2014) „Using common features to understand the behavior of metalcommodity prices and forecast them at different horizons", Journal of International Money and Finance, Vol. 42, pp. 310-335.
[20] Kabwe E., Yiming W., (2015) “Analysis of Copper s Market and Price - Focus on The Last Decade s Change And Its Future Trend“, IJSTR, Vol.4, issue 10, pp. 54-61.

[21] Labys W.C., Maizels A., (1993) “Impact of Commodity Price Fluctua-tions on the Developed Economies", Journal of Policy Modeling, Vol. 15, no. 3, pp. 335-352.

[22] Lazibat T., Matić B., (2002) "Fundamentalna i tehnička analiza cijena na terminskim tržištima“, Ekonomski pregled, Vol. 53(5-6), str. 507-524.

[23] Lee Eun Young, Shin Yi Seul (2018) Copper and Its Electrifying Future, DBS Group Research

[24] Luo X., (2007) "Study of Fundamental Analysis for Crude Oil Futures Prices", Dostupno na:

https://www.cs.uic.edu/ xluo/MISI Project/CrudeOil.html (pristupljeno: 20.12.2018)

[25] Miečinskiene A., Lapinskaitè I., (2014) "The Research on the Impact of the Changes of Commodity Price Level in the World Commodity Exchanges on Variation of General Price Level", Economics and Sociology, Vol. 7, no. 4, pp. 71-88.

[26] Mujačević E., Vizjak M., (2015) „Republika Kina nova svjetska gospodarska velesila“,

[27] Zbornik radova, ERAZ 2015, Beograd, str. 576-585.

[28] Petrović P.B., (2009) Berze i berzansko poslovanje, Institut za međunarodnu politiku i privredu, Beograd

[29] Radetzki M., (2009) "Seven Thousand Years in the Service of Humanity: The History of Copper, the Red Metal", Resources Policy, Vol 34, pp. 176-184.

[30] Ratti R. A., Vespignani J. L., (2015) "Commodity prices and BRIC and G3 liquidity: A SFAVEC approach", Journal of Banking \& Finance, Vol. 53, pp. 18-33. 
[31] Tan C.S., (1987) An Econometric Analysis of The World Copper Market, The World Bank, World Bank Staff Commodity Working Pappers, Washington D.C.

[32] The Observatory of Economic Complexity (2017) "Which Countries Import Copper Ore and Concentrates?", https://atlas.media.mit.edu/en/visualize /tree_map/hs92/import/show/all/ 260300/2017/

[33] USGS Mineral Commodity Summaries (2018) Data from USGS Mineral Commodity Summaries (2018), USGS, USA
[34] Van Gerwe T., (2016) Root Cause Analysis of Price Behaviour of Copper and Copper Market Volatility, Master Thesis, Delft University of Technology, Dostupno na: https://www.kitco.com/ commentaries/2018-06-20/Consider-theCurious-Case-of-Dr-Copper.html

[35] Vivoda V., (2011) "Determinants of foreign direct investment in the mining sector in Asia: A comparison between China and India“, Resources Policy, Vol. 36, pp. 49-59.

[36] Yang J., Li X., Liu Q., (2017) “China’s Copper Demand Forecasting Based on System Dynamics Model“", Dostupno na: https://www.preprints.org/ 